\title{
Energy and economic performance analysis of different ventilated wall construction types in residential buildings
}

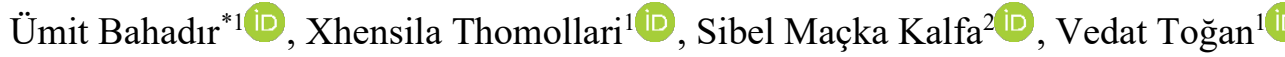 \\ ${ }^{1}$ Karadeniz Technical University, Department of Civil Engineering, Trabzon, Turkey \\ ${ }^{2}$ Karadeniz Technical University, Department of Architecture, Trabzon, Turkey
}

\begin{abstract}
Due to the increasing energy consumption in the world, energy efficiency has become the most important issue in sectors with high energy use such as industry, transportation, agriculture and construction. In many countries, the energy consumed in housing composes a large part of the total energy consumption. In Turkey, about $20 \%$ of total energy consumption is utilized in residential buildings and about $60 \%$ of this energy is used for heating. The energy consumed in residence buildings can be reduced by measures to decrease the heating and cooling loads. For this purpose, the main objective of this study is to investigate the effect of ventilated walls on the energy and cost performance of buildings. The energy and cost efficiency of 27 different ventilation walls with 3 different insulation thicknesses, 3 different ventilation gap thicknesses and 3 different cladding materials were compared with the reference wall. For a family of 3 , a flat with a $2+1$ plan was chosen for investigation and the flat is located in Trabzon, which represents the moderate-humid climate region. Flat plans with different ventilated walls were modeled using DesignBuilder energy simulation software and monthly/annual heating and cooling loads were obtained. Then, life cycle cost analysis has been conducted to investigate the cost effective ventilated wall types. Although the high initial investment costs of the investigated ventilated walls increase the life cycle costs, it has been observed that they provide energy savings in buildings.
\end{abstract}

\section{Keywords}

Cost efficiency; Energy efficiency; Life cycle cost; Residential buildings; Ventilated wall

Received: 25 November 2020; Accepted: 23 December 2020

ISSN: 2630-5771 (online) (C) 2020 Golden Light Publishing All rights reserved.

\section{Introduction}

In the last decades, increasing energy consumption due to problems such as population growth, technological developments, climate change and global warming is the most important subject for countries. Therefore, energy-efficient building design has been the focus of various research studies in the construction industry. Most of the energy demand in buildings is to balance heat gain and loss in order to maintain the thermal comfort of the interior zones. For this, building envelopes are of great importance in the final annual energy demand of buildings. For example, in buildings used for residential purposes, the heat lost through building envelope are respectively $25 \%$ in roofs, $25 \%$ in windows and doors, $20 \%$ in building structural system and $15 \%$ in walls. Also, the heat gains are $25-35 \%$ in roofs, $25-35 \%$ in windows, $15-25 \%$ in walls, $10-20 \%$ ground floors, and 5 $25 \%$ air infiltration [1]. Taking into consideration

* Corresponding author

Email: umitbahadir@ktu.edu.tr 
that, $80 \%$ of the total building stock in Turkey is residential building [2], fewer heat losses and gains are converted in reduced primary energy demand at the state level.

The energy performance of buildings can be increased with active and passive energy strategies. Using solar panels, improvements to heating, ventilation and air conditioning (HVAC) system, etc. are used as active measures, and increasing insulation thickness on the building envelope, using glass with low thermal conductivity are also implemented as passive measures [3]. With the increasing interest in passive measures in recent years, many researchers have examined the effects of changes in the building envelope on energy use. Generally, these studies have focused on the embodied energy used in the construction phase, and the operation energy required for HVAC, hot water and devices. Optimization techniques have been developed to reduce the embodied energy by using less concrete during the construction phases of buildings [4]. In a similar study, an optimization method was developed to reduce the embodied energy and carbon dioxide (CO2) emissions of the column [5].

The operation energy consumed by the buildings during their life cycle is more than the embodied energy [6]. Several studies are reported in the literature for building envelope materials and parameters to reduce operation energy. Among these studies, changing the different parameters of the building envelope in a reference building and finding the scenario with the most energy efficient combinations are a topic of great importance [7-10]. For example, Mirrahimi et al. [11] showed that building envelope parameters (window/wall ratio, wall type, building orientation, glazing, etc.) have a significant effect on energy savings and thermal comfort in a hot-humid climate. Jalilzadehazhari et al. [12] aimed to achieve a trade-off solution decision making in the selection of design alternative where three types of energy-efficient windows and five types of ground floors, roofs, and external wall constructions were considered as optimization variables. Altun et al. [13] examined the effects of insulation improvements on annual energy savings, life cycle cost savings and life cycle carbon footprint and achieved improvements of $75 \%, 70 \%$ and $73 \%$, respectively. Later on, Aydin and Bıyıklığlu [14] presented that the energy savings achieved by optimum insulation thicknesses determined by life cycle cost analysis (LCCA) varies between $12.9 \%$ and $21.5 \%$ depending on the degree-day regions. In another study on insulation thickness, it was found that optimum thickness glass wool and rockwool insulation materials reduce fuel consumption by approximately $70 \%$ and $40 \%$ [15]. According to Ozalp et al. [16], the effect of wall building material on heat losses is much higher than insulation material. Some researchers analysed the impact of innovative façade (double skin façade, BIPV façade, opaque ventilated façade, greenery systems etc.) in the energy performance of the building by numerical or experimental methods. In these studies, it was concluded that the pros and cons of implementing this typology of walls in buildings with different climate conditions [17-19]. Aldawoud et al. [20] investigated the effects of different design scenarios on the airflow and energy performance of an office building with a double skin facade in Dubai city. The scenarios were compared with traditional curtain wall systems and it was seen that the energy performance varies according to the construction characteristics and the width of the air gap. A potential reduction of $22 \%$ in annual cooling energy consumption has been achieved. Few studies related to the performance of ventilated façade have shown a reduction of 20 $40 \%$ of cooling energy demand. However, this reduction is correlated to parameters as thermal performance of the layers, insulation status of the inner façade, the height and the width of the air cavity, the type of ventilation, the climatic context, solar exposure, and wind status [21-24].

As can be understood from the current literature, there are few studies on the innovative wall in Turkey. The aim of this study is to determine the energy performance and life cycle costs of ventilated walls on residential buildings located in moderate-humid climate regions of Turkey. Energy and cost-efficient design alternatives of ventilated 
walls are focused on obtaining by changing the insulation thickness, ventilation gap thickness and cladding material.

\section{Methodology}

In the study, a high-rise residential project with a $2+1$ floor plan for a family of three is used in Turkey, which comprises a total of two flats. The studied building is located in Trabzon, in climate region II, in a moderate-humid climate. The effects of ventilated walls with different insulation material thickness, different ventilation gap thickness and different cladding materials on the heating and cooling loads of the buildings compared to the reference wall were investigated. In this context, energy performance analysis has been made by keeping constant all parameters except wall construction types. Heating and cooling loads, which correspond to different wall types, were calculated monthly and annually by the DesignBuilder, dynamic building energy simulation software. Then, for each ventilated wall type, the life cycle costs were calculated by summing the initial capital investment and the annual energy operational cost. Finally, the energy and cost efficiency of the wall construction types according to obtained heating and cooling loads were investigated and the most suitable alternative was determined in Trabzon.

\subsection{Building information}

The investigated building consists of 8 floors and 2 flats on each floor. Each flat is $108.6 \mathrm{~m}^{2}$. A flat, with six thermal zones, has one living room+kitchen, one toilet, two bedrooms and two bathrooms. The floor plan and zones for two flats are shown in Fig. 1. The height of flat is $2.8 \mathrm{~m}$.

Investigated building was located in Trabzon, in Climate Region II, representing the moderatehumid climate of Turkey. Meteorological data for Turkey's moderate-humid climate are obtained from the Turkish State Meteorological Service [25].

The study made taking into account the intermediate floor. The physical properties and heat transfer coefficient values (U-value, $\mathrm{W} / \mathrm{m}^{2} \mathrm{~K}$ ) of the partition wall, ceiling and floor components are given in Table 1, listed from the outer to the interior surface. The ceiling and floor constructions are the same because the investigated flats are on intermediate floors. The windows $(3+13+3 \mathrm{~mm})$ for each apartment created using different concrete mixtures are the same on all facades and the window/wall ratio is $30 \%$.

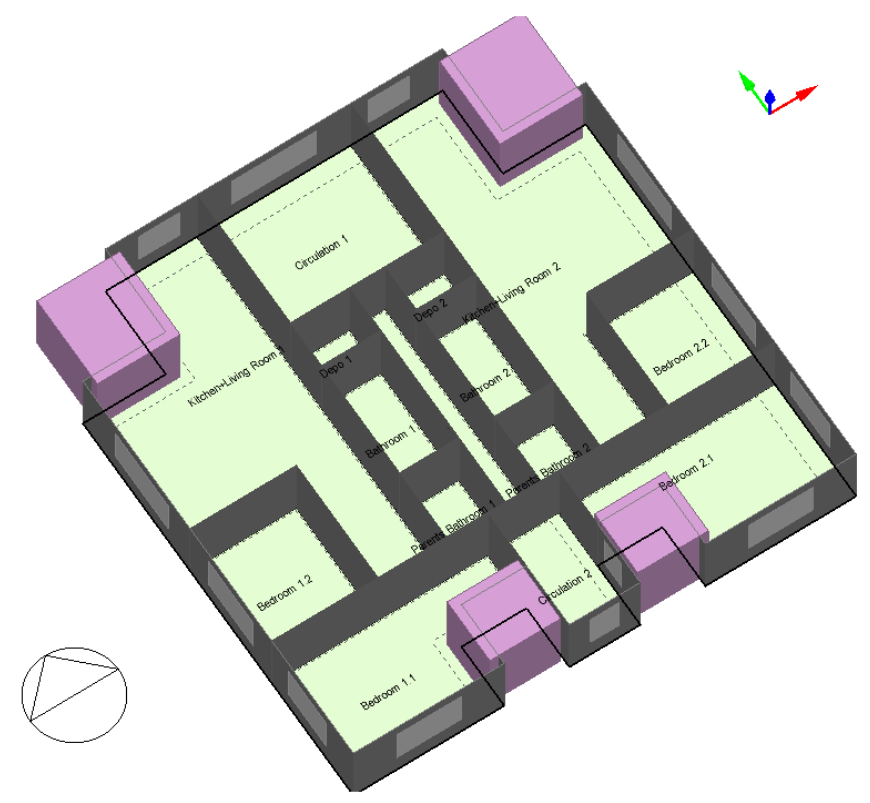

Fig. 1. Flats model 
Table 1. Properties of materials and building components

\begin{tabular}{|c|c|c|c|c|c|c|}
\hline & Materials & $\begin{array}{c}\text { Thickness } \\
\text { (mm) }\end{array}$ & $\begin{array}{l}\text { Density } \\
\left(\mathrm{kg} / \mathrm{m}^{3}\right)\end{array}$ & $\begin{array}{c}\text { Specific heat } \\
\text { capacity } \\
(\mathrm{J} / \mathrm{kg} \mathrm{K})\end{array}$ & $\begin{array}{c}\text { Thermal } \\
\text { conductivity } \\
(\mathrm{W} / \mathrm{mK})\end{array}$ & $\begin{array}{l}\text { U-value } \\
\left(\mathrm{W} / \mathrm{m}^{2} \mathrm{~K}\right)\end{array}$ \\
\hline \multirow{3}{*}{ Partition wall } & Gypsum plaster & 20 & 1000 & 1000 & 0.40 & \multirow{3}{*}{2.618} \\
\hline & Brick & 85 & 1700 & 800 & 0.84 & \\
\hline & Gypsum plaster & 20 & 1000 & 1000 & 0.4 & \\
\hline \multirow{4}{*}{ Ceiling } & Carpet & 20 & 200 & 1300 & 0.06 & \multirow{4}{*}{1.246} \\
\hline & Mortar & 40 & 2800 & 896 & 0.88 & \\
\hline & Concrete & 140 & 1800 & 1000 & 1.35 & \\
\hline & Gypsum plaster & 20 & 1000 & 1000 & 0.4 & \\
\hline \multirow{4}{*}{ Floor } & Gypsum plaster & 20 & 1000 & 1000 & 0.4 & \multirow{4}{*}{1.347} \\
\hline & Concrete & 140 & 1800 & 1000 & 1.35 & \\
\hline & Mortar & 40 & 2800 & 896 & 0.88 & \\
\hline & Carpet & 20 & 200 & 1300 & 0.06 & \\
\hline
\end{tabular}

The flats were considered the home of a family of three with two working adults and a studying child. Equipment such as miscellaneous (television, refrigerator etc.) and computer were assumed to be used in the flats. All zones in the flats are heated and cooled. Natural gas is used for heating and air conditioner running on electricity is used for cooling. Heating and cooling setpoint temperatures are $18^{\circ} \mathrm{C}$ and $22^{\circ} \mathrm{C}$, respectively.

\subsection{Building wall scenarios}

In order to examine the effects of ventilated walls on annual heating and cooling loads and life cycle cost of buildings, the energy and cost performances of the reference and ventilated walls were compared. Therefore, 27 different types of ventilated walls were obtained by using 3 different thickness (50-80-100 $\mathrm{mm}$ ) insulation material (rockwool), 3 different thickness (50-100-150 mm) ventilation gaps and 3 different types of cladding materials (wood, stone and green). The reference and ventilated walls used in this study are illustrated in Fig. 2. The abbreviations of examined ventilated walls according to the changing layers are shown in Table 2. The thermal properties of the materials are also given in Table 3.

\subsection{Life cycle cost analysis}

In the study, LCCA was used to find the cost efficiency of the investigated wall types. LCCA determines the most cost-effective option among different alternatives for the total cost of purchasing, operating, maintaining/repairing and disposing of equipment [26]. To evaluate the life cycle cost of equipment, all future costs during the unit life, with the exception of the initial capital investment of the project, are discounted to the present value. The life cycle cost (LCC) formula is shown below:

$L C C=I+M-R-O+R-R V$

Square-meter unit prices of the wall materials in this study were obtained from the Republic of Turkey Ministry of Environment and Urbanisation and from the material companies in Turkey. While unit prices of the wall materials are shown in Table 4 , Table 5 gives the initial capital investment for the investigated walls. Each flat has an external wall of $90.725 \mathrm{~m}^{2}$ and initial capital investments were calculated taking into account the quantity of the external wall. Within the scope of the study, only the initial capital investment and operating costs were taken into consideration, as the certain data on maintenance and repair costs were not available in the Republic of Turkey Ministry of Environment and Urbanisation and Turkish material companies. When calculating operating costs, annual energy expenditures were used. In the calculations made for a period of 30 years, energy expenditures are calculated using the present worth analysis method and a $15 \%$ discount rate. 


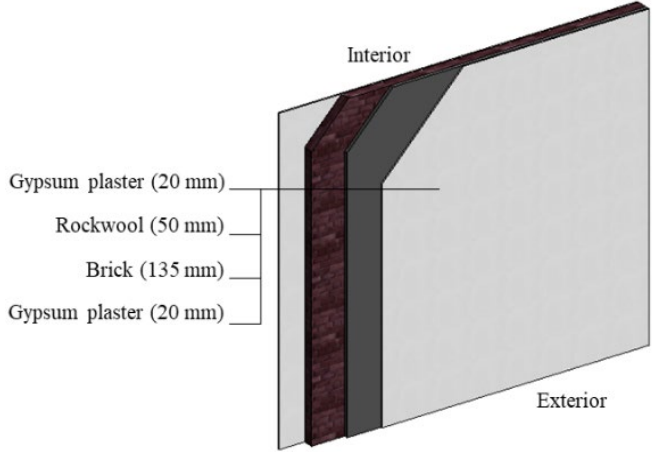

a) Reference wall

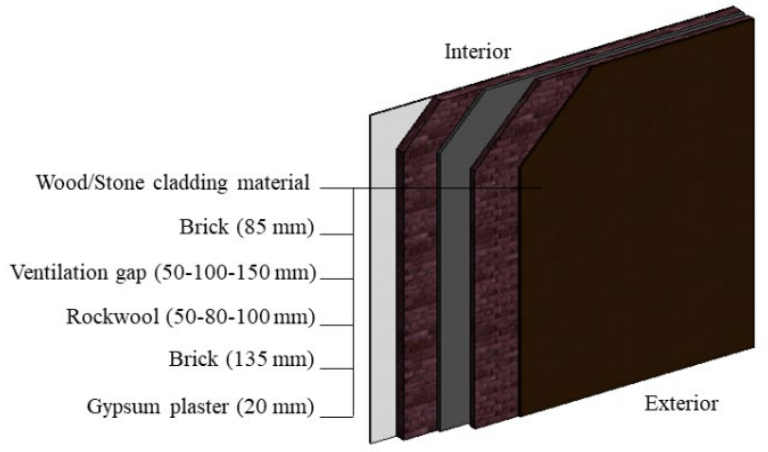

b) Wood and stone ventilated wall

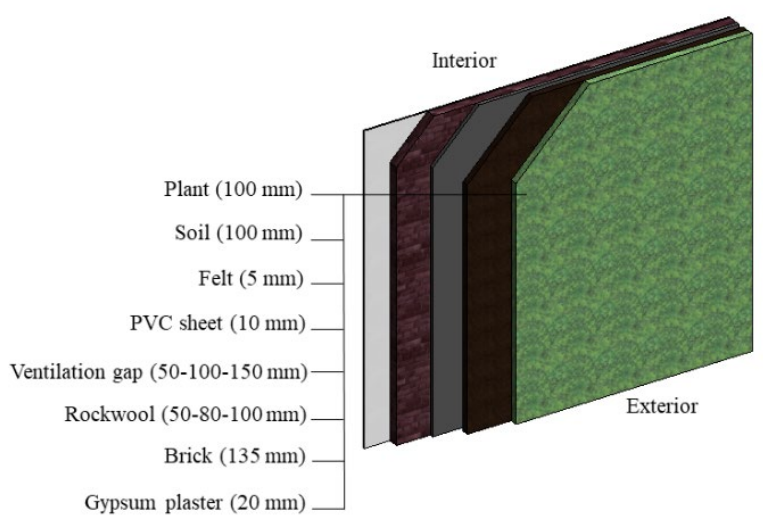

c) Green ventilated wall

Fig. 2. Walls used in the study

Table 2. Abbreviations and changing layers of walls

\begin{tabular}{lccc}
\hline Wall types & Rockwool thickness $(\mathrm{mm})$ & Ventilation gap thickness $(\mathrm{mm})$ & Cladding materials \\
\hline VW-1 & 50 & 50 & Wood \\
VW-2 & 50 & 100 & Wood \\
VW-3 & 50 & 150 & Wood \\
VW-4 & 80 & 50 & Wood \\
VW-5 & 80 & 100 & Wood \\
VW-6 & 80 & 150 & Wood \\
VW-7 & 100 & 50 & Wood \\
VW-8 & 100 & 100 & Wood \\
VW-9 & 100 & 150 & Wood \\
VW-10 & 50 & 50 & Stone \\
VW-11 & 50 & 100 & Stone \\
VW-12 & 50 & 150 & Stone \\
VW-13 & 80 & 50 & Stone \\
VW-14 & 80 & 100 & Stone \\
VW-15 & 80 & 150 & Stone \\
VW-16 & 100 & 50 & Stone
\end{tabular}


Table 2. Cont'd

\begin{tabular}{lccc} 
VW-17 & 100 & 100 & Stone \\
VW-18 & 100 & 150 & Stone \\
VW-19 & 50 & 50 & Green \\
VW-20 & 50 & 100 & Green \\
VW-21 & 50 & 150 & Green \\
VW-22 & 80 & 50 & Green \\
VW-23 & 80 & 100 & Green \\
VW-24 & 80 & 150 & Green \\
VW-25 & 100 & 50 & Green \\
VW-26 & 100 & 100 & Green \\
VW-27 & 100 & 150 & Green \\
\hline
\end{tabular}

Table 3. Properties materials used in the ventilated walls

\begin{tabular}{lccc}
\hline Material & Density $\left(\mathrm{kg} / \mathrm{m}^{3}\right)$ & Specific heat capacity $(\mathrm{J} / \mathrm{kg} \mathrm{K})$ & Thermal conductivity $(\mathrm{W} / \mathrm{mK})$ \\
\hline Wood & 720 & 1680 & 0.14 \\
Stone & 2300 & 1000 & 1.8 \\
Plant & 110 & 1880 & 0.14 \\
Soil & 1460 & 880 & 1.28 \\
Ventilation gap & 1.2 & 1012 & 0.023 \\
Rockwool & 100 & 710 & 0.033 \\
Brick & 1700 & 800 & 0.84 \\
Gypsum plaster & 1000 & 1000 & 0.4 \\
\hline
\end{tabular}

Table 4. Unit prices of wall materials

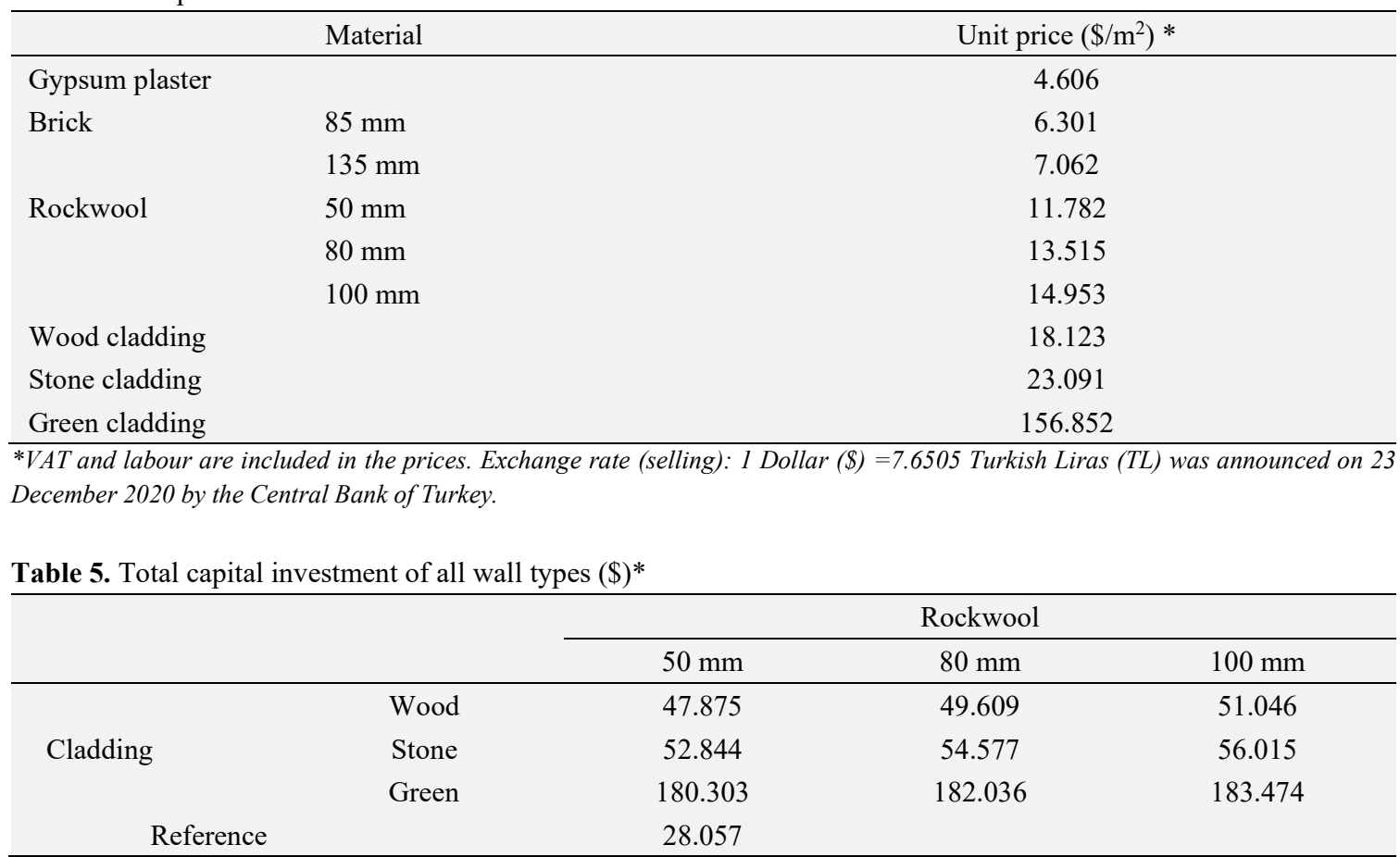

* The total capital investments of the other 18 combinations are the same costs given above because prices do not change with ventilation gap thicknesses. 
Unit prices of electricity and natural gas for Trabzon were obtained to calculate annual energy expenditures from the websites of distributor companies [27, 28]. Other factors using in the LCCA are shown in Table 6.

\section{Results and discussions}

Heating and cooling loads and related life cycle costs were obtained for the flats examined with the simulation. With these data, evaluations are made for the energy and cost effective ventilated wall types in Trabzon, with a moderate-humid climate.

\subsection{Energy performance}

In this section, the monthly heat gains/losses and annual heating and cooling loads of the building through investigated wall types were analysed according to the cladding materials. The values in the heat gains/losses figures demonstrate the average monthly net energy flows through the walls. Net energy flows were obtained by summing heat gains/losses for each month from the simulation results.

\subsubsection{Wood cladding ventilated wall scenarios}

When the performance of the wood cladding walls in terms of monthly heating and cooling loads was examined, it was found that they lost less heat compared to the reference wall, as seen in Fig. 3. Annual energy savings between 58\% (VW-1) and $82 \%$ (VW-9) were achieved with wood cladding ventilated walls. The heat losses rates during the heating period (from the beginning of October until the end of March) are similar to the annual rates.

Fig. 4 shows the annual heating and cooling loads of wood cladding ventilated walls. Compared

Table 6. Parameters used in the LCCA

\begin{tabular}{lc}
\hline Analysis type & General LCCA-non-federal, no taxes \\
\hline Beginning date & 2018 \\
Study period & 30 years \\
Planning/Construction period & 2 years \\
Discount rate & $15 \%$ \\
Fuel type & Natural gas and electricity \\
The unit cost of natural gas (for 2020) & $0.0245 \$ / \mathrm{kWh} *$ \\
The unit cost of electricity (for 2020$)$ & $0.0898 \$ / \mathrm{kWh} *$ \\
\hline
\end{tabular}

to the reference wall for all walls, the heating and cooling load requirement decreases between 3-9\% and $9-13 \%$, respectively. When analysed annually, energy savings up to 11 percent are achieved. VW9 is the best performance wood cladding ventilated wall in terms of heating and cooling loads.

\subsubsection{Stone cladding ventilated wall scenarios}

As shown in Fig. 5, stone cladding ventilated walls show better performance in terms of heat loss compared to reference walls. During the heating period and all months, fewer heat losses were achieved, ranging from an average of $58 \%$ (VW10) to $82 \%$ (VW-18).

Considering the contribution of stone cladding ventilated walls to annual heating and cooling loads, it is seen that they reduce the total load between $6 \%$ and $11 \%$. As can be seen in Fig. 6, there has been a decrease up to $890.23 \mathrm{kWh}$ in cooling load and $988.37 \mathrm{kWh}$ in heating load. This shows that stone cladding ventilated walls performed better performance than the reference wall, according to energy saving.

\subsubsection{Green cladding ventilated wall scenarios}

When the heat gains/losses of the green cladding ventilated walls are examined, VW-27 reduces the heat loss during the heating period by $84 \%$. They also reduce heat losses in all months between $63 \%$ and $82 \%$. The heat gains/losses of these walls as regards the reference wall are shown in Fig. 7.

It can be seen from Fig. 8 that green cladding ventilated walls reduce the annual heating and cooling load between $8 \%$ and $14 \%$ and between $10 \%$ and $13 \%$, respectively. $\mathrm{VW}-27$ reduces the total load by $11 \%$ and is obtained as the best energy-saving green cladding ventilated wall.

*VAT is included in the prices 


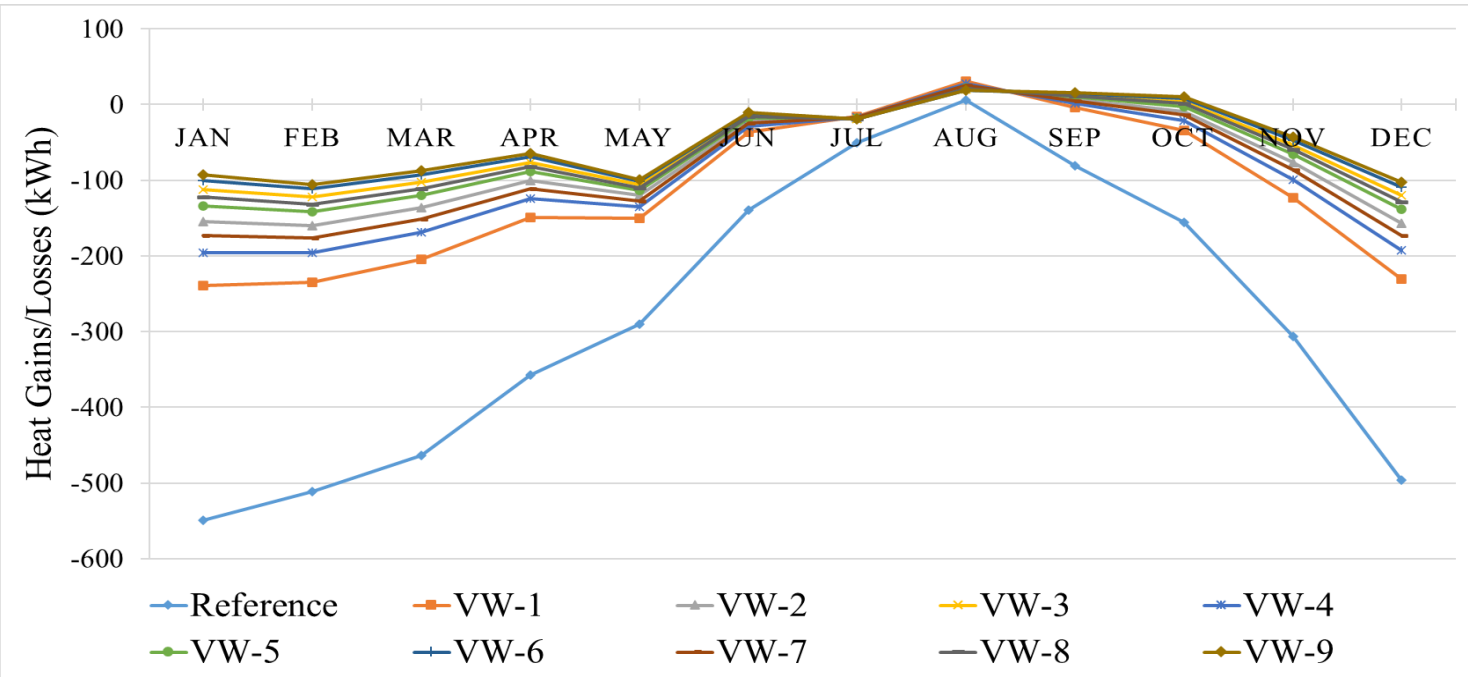

Fig. 3. Monthly heat gains/losses through wood cladding walls

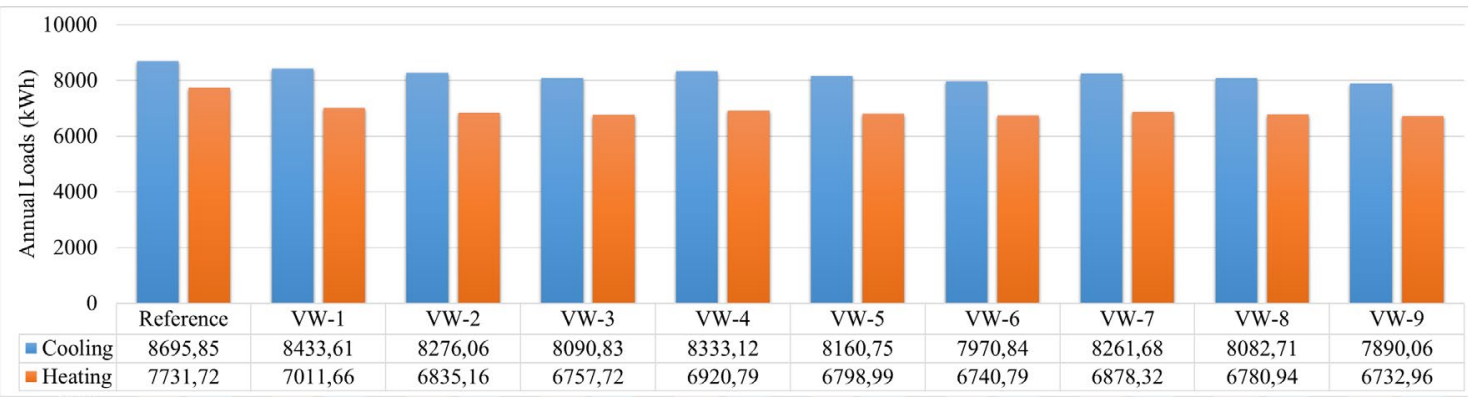

Fig. 4. Annual total building cooling and heating loads for wood cladding walls

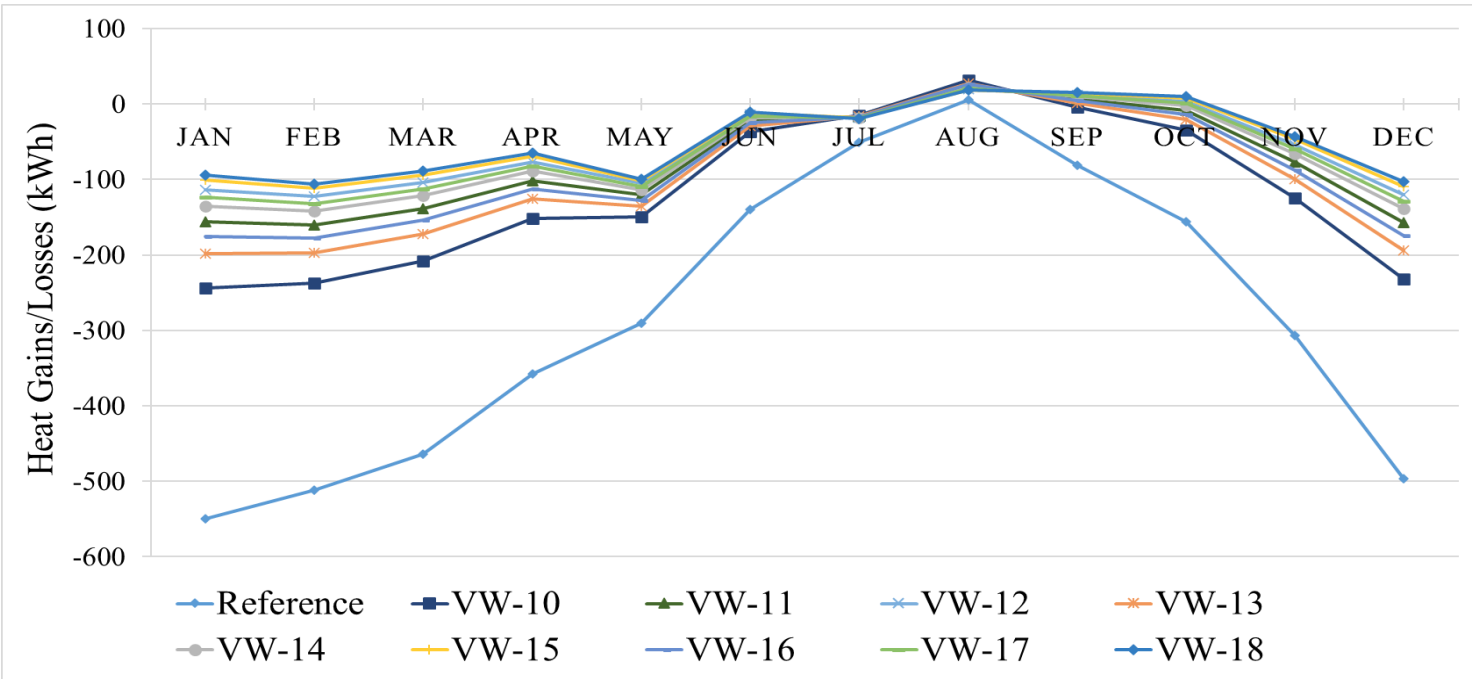

Fig. 5. Monthly heat gains/losses through stone cladding walls 


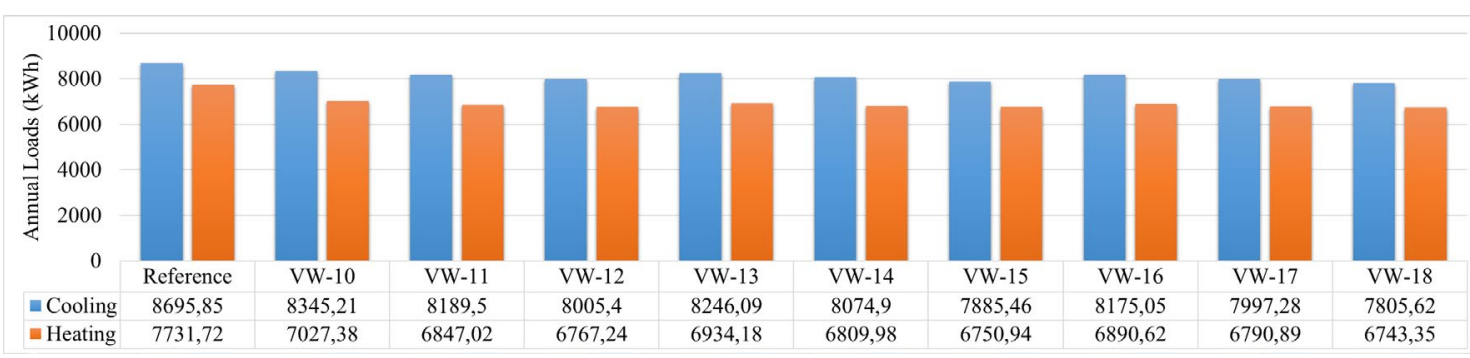

Fig. 6. Annual total building cooling and heating loads for stone cladding walls

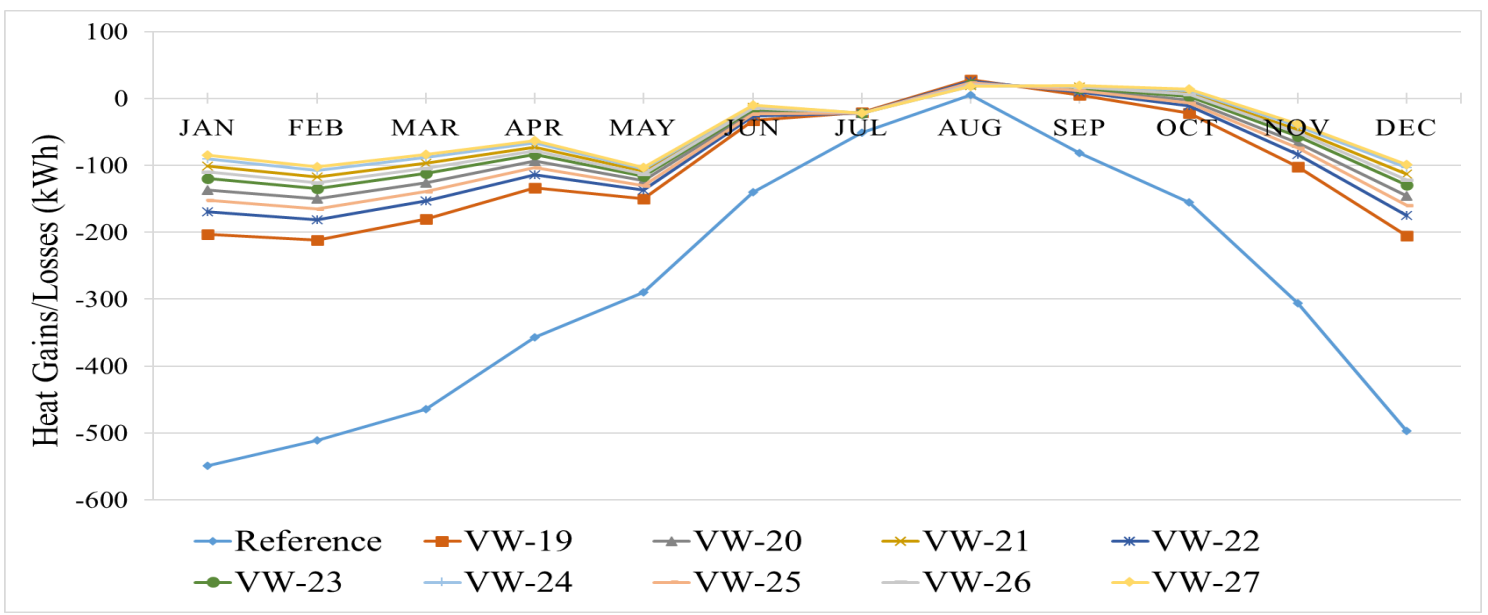

Fig. 7. Monthly heat gains/losses through green cladding walls

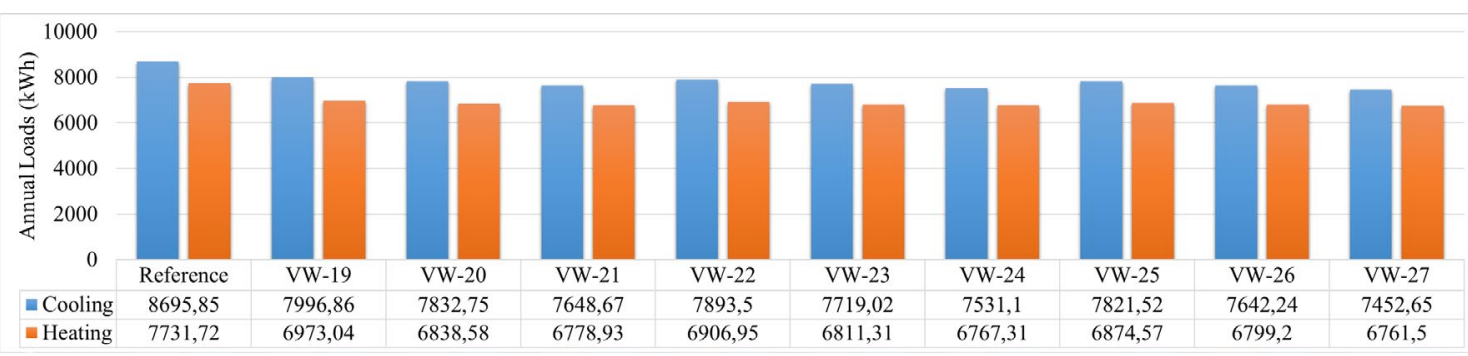

Fig. 8. Annual total building cooling andheating loads for green cladding walls

\subsubsection{Comparing all scenarios in terms of energy performance}

As shown in monthly heat gains/losses Figs., all ventilated wall types reduce heat losses compared to the reference wall. The decrease in heat losses during the heating period will result in less energy consumption. All ventilated wall types provide between $58 \%$ and $84 \%$ energy savings during the heating period. The same percentage of savings has been obtained in the total annual heat gain/loss. VW-9 wall as a wood cladding wall, VW-18 wall as a stone cladding wall and VW-27 wall as a green cladding wall give the best results in terms of annual heat losses in ventilated walls. These 3 ventilated walls prevented heat loss at approximately the same rate. In addition, most ventilated wall types have heating gains in August and September in the cooling period (from the beginning of April until the end of September).

All ventilated walls have higher energy performance than the reference wall for cooling and heating loads. The most energy-saving ventilated 
wall types for each cladding material and their cooling and heating loads are shown in Fig. 9. It was obtained that ventilated walls reduce the cooling load between $3 \%$ to $14 \%$ and the heating load between $9 \%$ to $13 \%$. VW-27 shows the best performance in terms of cooling and VW-3, VW-6, VW-9, VW-15, VW-18 and VW-27 provide the lowest energy need in terms of heating. In addition, the investigated ventilated walls cause between $6 \%$ and $13 \%$ higher total annual energy savings. The annual energy savings of VW-24 and VW-27 is the highest compared to other wall types.

From these results, it is observed that cooling load decreases as the thickness of the insulation material and ventilation gap increases and as the cladding material changes from wood to green. In terms of heating loads, it is seen that a definite conclusion cannot be reached among the cladding materials. However, it is concluded that the heating load decreases as the insulation thickness and ventilation gap increase.

\subsection{Economic and energy performance of all scenarios}

In this section, it is aimed to achieve cost effective ventilated wall combinations as well as energy. For this, LCCA of each ventilated wall was carried out. The annual energy expenditures of the wall types used in the study obtained from the annual loads for heating and cooling are given in Table 7.
Table 7. Annual energy expenditures of all wall types (\$)

\begin{tabular}{|c|c|}
\hline Wall types & Annual energy expenditure (\$) \\
\hline Reference & 970.6893 \\
\hline VW-1 & 929.4771 \\
\hline VW-2 & 910.9972 \\
\hline VW-3 & 892.4602 \\
\hline VW-4 & 918.2224 \\
\hline VW-5 & 899.7527 \\
\hline VW-6 & 881.2670 \\
\hline VW-7 & 910.7639 \\
\hline VW-8 & 892.3002 \\
\hline VW-9 & 873.8190 \\
\hline VW-10 & 921.9221 \\
\hline VW-11 & 903.5129 \\
\hline VW-12 & 885.0199 \\
\hline VW-13 & 910.7333 \\
\hline VW-14 & 892.3108 \\
\hline VW-15 & 873.8467 \\
\hline VW-16 & 903.2841 \\
\hline VW-17 & 884.8705 \\
\hline VW-18 & 866.4891 \\
\hline VW-19 & 889.2993 \\
\hline VW-20 & 871.2611 \\
\hline VW-21 & 853.2636 \\
\hline VW-22 & 878.3945 \\
\hline VW-23 & 860.3767 \\
\hline VW-24 & 842.4180 \\
\hline VW-25 & 871.1349 \\
\hline VW-26 & 853.1831 \\
\hline VW-27 & 835.2289 \\
\hline
\end{tabular}

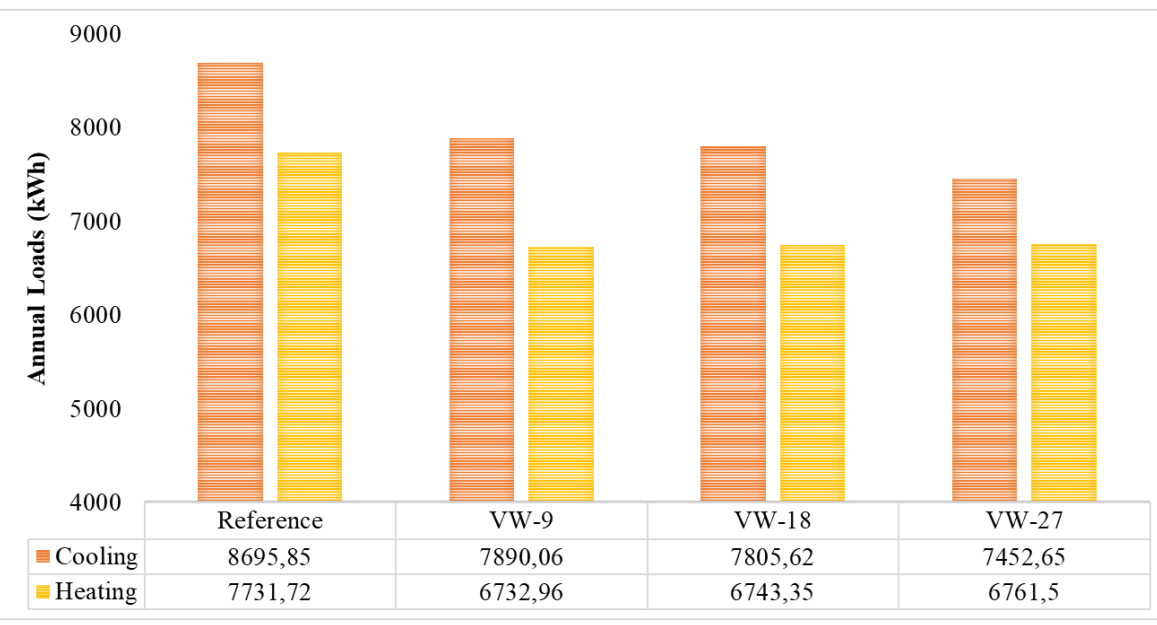

Fig. 9. Annual total building cooling and heating loads for reference and ventilated walls 
Energy expenditures decrease between $4 \%$ and $14 \%$, equivalent to the decreasing annual load. Thus, cost savings up to $135.4604 \$$ per year can be achieved compared to the reference wall.

Figs. 10, 11 and 12 show the total annual loads and related life cycle costs of 9 combinations in each cladding material. All wall types are more expensive than reference wall as regards LCCA. VW-3, VW-12 and VW-21 have been obtained as the most suitable wall type in each combination of cladding materials. Especially since the initial investment cost of green walls is much higher than other walls, the life cycle cost of green cladding walls is even more than $100 \%$ than other wall types.

According to these Figs., it is seen that the most effective ventilated wall types for each coating material in terms of energy and cost are not the same. Fig. 13 shows the total loads and life cycle costs of the best combinations of each different cladding ventilated wall compared to the reference wall. VW-9 is the best energy combination with an $11 \%$ reduction, while $\mathrm{VW}-3$ is the cheapest alternative in wood cladding ventilated walls. Also, VW-18 saves $223.67 \mathrm{kWh}$ more energy annually than VW-12, which is the cheapest alternative in stone cladding ventilated walls. Similarly, although the VW-27 consumes $2 \%$ less energy than VW-21 in green cladding ventilated walls, the life cycle cost is approximately $169.27 \$$ more. These results show that the life cycle costs of walls with $50 \mathrm{~mm}$ rockwool and $150 \mathrm{~mm}$ ventilation gap are less than other combinations and that walls with $100 \mathrm{~mm}$ rockwool and $150 \mathrm{~mm}$ ventilation gap are the most energy efficient walls. According to the type of cladding material, the life cycle costs are listed as green, stone and wood from expensive to cheap.

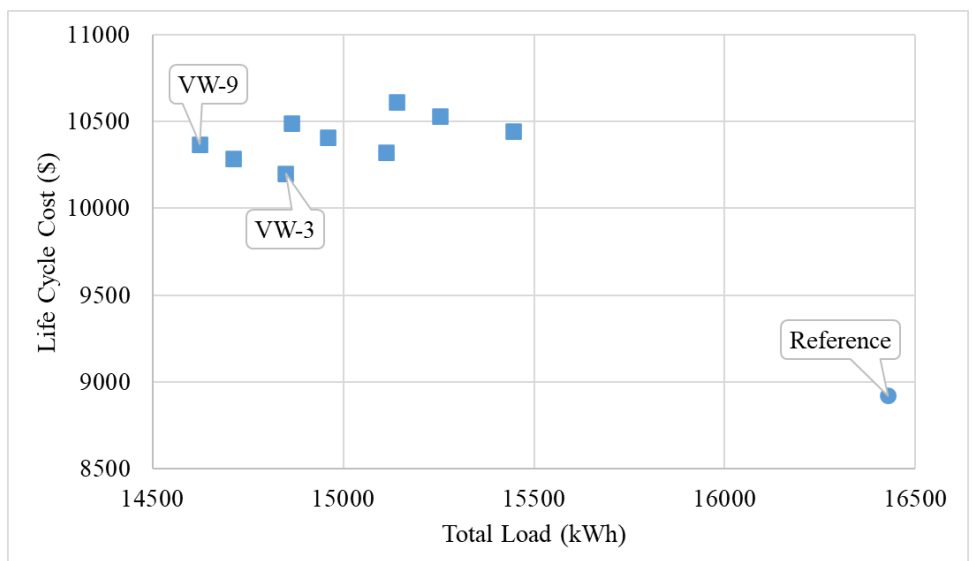

Fig. 10. Annual total loads and life cycle costs of wood cladding wall combinations and reference

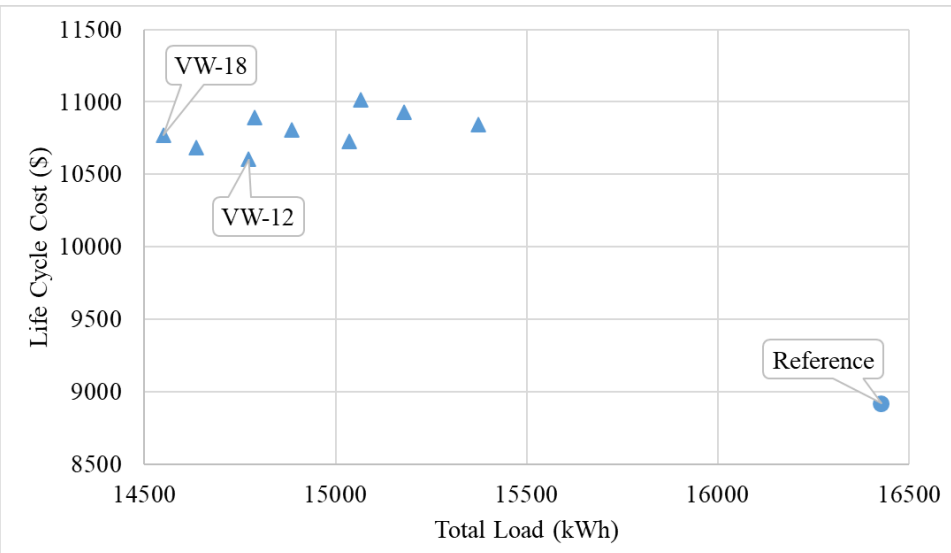

Fig. 11. Annual total loads and life cycle costs of stone cladding wall combinations and reference 


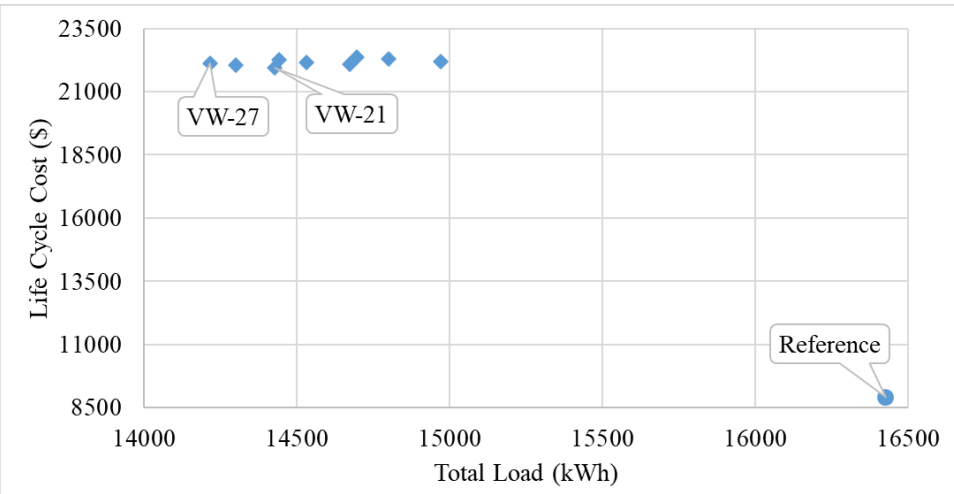

Fig. 12. Annual total loads and life cycle costs of green cladding wall combinations and reference

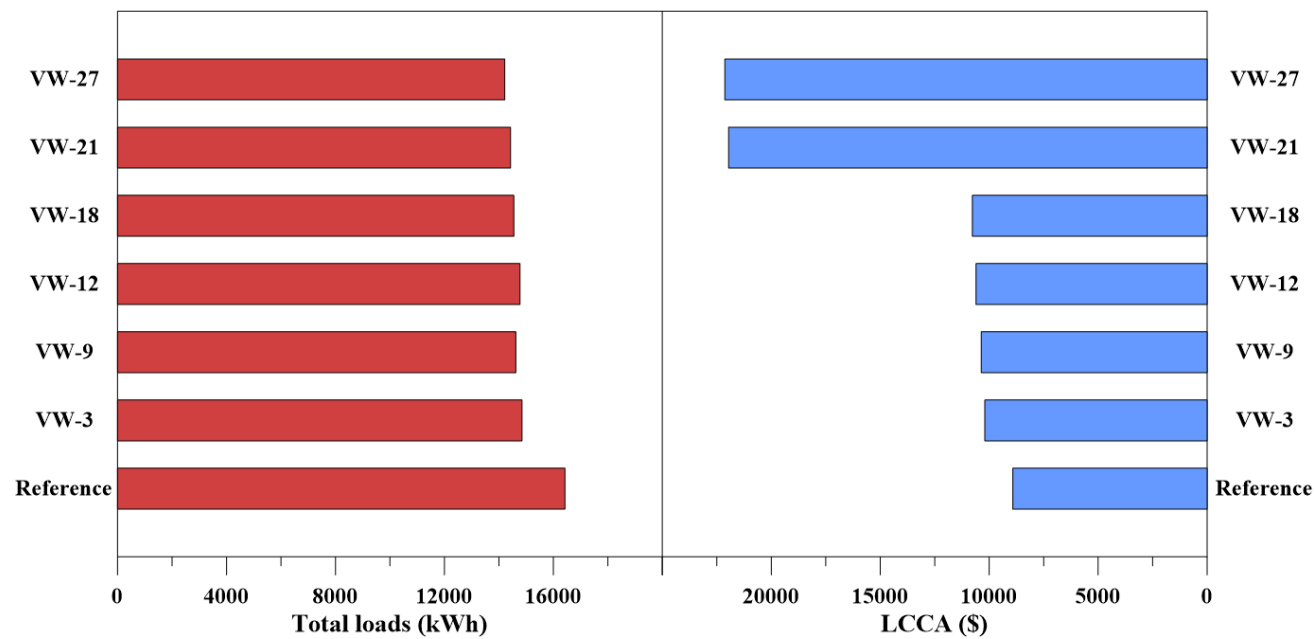

Fig. 13. Comparison of energy and economic alternatives of the ventilated walls

\section{Conclusion}

In the study, in order to investigate the effect of ventilated walls on energy and cost performance in buildings was studied on an apartment designed for a three-person family in a moderate-humid climate zone. By using different insulation material thickness, different ventilation gap thickness and different wall cladding material, 27 walls were obtained and the energy and economy performance of each wall type was examined and compared to the reference walls. The following conclusions are drawn:

- Heat losses decrease between $57 \%$ and $84 \%$ compared to the reference in all examined wall types. VW-9, VW-18 and VW-27 walls of each cladding material are the best walls in terms of heat losses. These walls have a $100 \mathrm{~mm}$ rockwool and a $150 \mathrm{~mm}$ ventilation gap.

- For heating and cooling energy savings, all investigated ventilated wall types are more efficient than the reference wall. The cooling and heating loads are reduced between $3 \%$ and $14 \%$ and $9 \%$ and $13 \%$, respectively.

- Considering annual energy consumption, the examined walls consume between $6 \%$ and $13 \%$ less annual energy.

- When the annual energy expenditures are analysed, it is seen that the energy cost is reduced between $41.2122 \$$ and $135.4604 \$$.

- Increasing insulation material thickness and ventilation gap decreased heating and cooling loads. While green cladding material is the most 
effective material in reducing cooling loads, wood is the most efficient material in terms of the heating load.

- As a result of the LCCA, it was found that the high initial investment costs, as in the case of green cladding walls, caused the ventilated walls to be economically ineffective compared to the reference wall.

Consequently, it has been determined that the analysed wall types are energy efficient, although not economically efficient in the moderate-humid climate zone. In the future, studies can be performed for other climate zones in Turkey. In addition, similar studies can be made for other wall types that are thought to be energy efficient. Performing energy optimization by using other parameters that affect the energy performance of buildings can provide more information about energy efficiency.

\section{Declaration of conflicting interests}

The author(s) declared no potential conflicts of interest with respect to the research, authorship, and/or publication of this article.

\section{References}

[1] NIRAS. Energy Systems and Measurement Methods in Buildings. 2016.

[2] Sağlam NG, Yılmaz AZ, Becchio C, Corgnati SP (2017) A comprehensive cost-optimal approach for energy retrofit of existing multi-family buildings: Application to apartment blocks in Turkey. Energy and Buildings 150: 224-238.

[3] Sadineni SB, Madala S, Boehm RF (2011) Passive building energy savings: A review of building envelope components. Renewable and Sustainable Energy Reviews 15(8): 3617-3631.

[4] Penadés-Plà V, García-Segura T, Yepes V (2019) Accelerated optimization method for lowembodied energy concrete box-girder bridge design. Engineering Structures 179: 556-565.

[5] Yoon YC, Kim KH, Lee SH, Yeo D (2018) Sustainable design for reinforced concrete columns through embodied energy and $\mathrm{CO}_{2}$ emission optimization. Energy and Buildings 174: 44-53.

[6] Ramesh T, Prakash R, Shukla KK (2010) Life cycle energy analysis of buildings: An overview. Energy and Buildings 42: 1592-1600.
[7] Gülten A (2020) Determination of optimum insulation thickness using the entransy based thermoeconomic and environmental analysis: a case study for Turkey. Energy Sources, Part A: Recovery, Utilization, and Environmental Effects 42(2): 219-232.

[8] Saylam Canım D, Aydın Ö (2019) Energy performance evaluation of energy performance calculation method in buildings (Bep-Tr1). Journal of Construction Engineering, Management \& Innovation 2(1): 18-29.

[9] Bahadır Ü, Thomollari X, Toğan V (2018) Evaluation of energy-cost efficient design alternatives for residential buildings. Journal of Construction Engineering, Management \& Innovation 1(1): 43-54.

[10] Saadatian SS, Freire F, Simões N (2016) Comparative life-cycle analysis of insulation materials in a dwelling, addressing alternative heating systems and life spans. Journal of Clean Energy Technology 4(6): 4-7.

[11] Mirrahimi S, Mohamed MF, Haw L, Ibrahim NLN, Yusoff WFM, Aflaki A (2016) The effect of building envelope on the thermal comfort and energy saving for high-rise buildings in a hothumid climate. Renewable and Sustainable Energy Reviews 53: 1508-1519.

[12] Jalilzadehazhari E, Vadiee A, Johansson P (2019) Achieving a trade-off construction solution using BIM, an optimization algorithm, and a multicriteria decision-making method. Buildings 81(9): $1-14$.

[13] Altun M, Meral Akgül Ç, Akçamete A (2020) Effect of envelope insulation on building heating energy requirement, cost and carbon footprint from a life-cycle perspective. Journal of the Faculty of Engineering and Architecture of Gazi University 35(1) 147-163.

[14] Aydin N, Biyikoğlu A (2020) Determination of optimum insulation thickness by life cycle cost analysis for residential buildings in Turkey. Science and Technology for the Built Environment 1-19.

[15] Dombayci AO, Ulu EY, Guven S, Atalay O, Ozturk HK (2020) Determination of optimum insulation thickness for building external walls with different insulation materials using environmental impact assessment. Thermal Science 24(1A): 303-311.

[16] Ozalp C, Saydam DB, Çerçi KN, Hürdoğan E, Moran H (2019) Evaluation of a sample building with different type building elements in an 
energetic and environmental perspective. Renewable and Sustainable Energy Reviews 115: 109386.

[17] Mytafides CK, Dimoudi A, Zoras S (2017) Transformation of a university building into a zero energy building in Mediterranean climate. Energy and Buildings 155: 98-114.

[18] Omrany H, Ghaffarianhoseini A, Ghaffarianhoseini A, Raahemifar K, Tookey J (2016) Application of passive wall systems for improving the energy efficiency in buildings: A comprehensive review. Renewable and Sustainable Energy Reviews 62: 1252-1269.

[19] Aparicio-Fernández C, Vivancos JL, FerrerGisbert P, Royo-Pastor R (2014) Energy performance of a ventilated façade by simulation with experimental validation. Applied Thermal Engineering 66(1-2): 563-570.

[20] Aldawoud A, Salameh T, Ki Kim Y (2020) Double skin façade: Energy performance in the United Arab Emirates. Energy Sources, Part B: Economics, Planning, And Policy 1-19.

[21] Sarihi S, Saradj FM, Faizi M (2021) A critical review of façade retrofit measures for minimizing heating and cooling demand in existing buildings. Sustainable Cities and Society 64: 102525.

[22] Maciel ACF, Carvalho MT (2019) Operational energy of opaque ventilated façades in Brazil. Journal of Building Engineering 25: 100775.

[23] Silva LFBD, Thomaz E, Oliveira LAD (2018) Ventilated cladding systems: structural and drainability performance criteria. Ambiente Construido 18(3): 341-358.

[24] Theodosiou T, Tsikaloudaki K, Bikas D (2017) Analysis of the thermal bridging effect on ventilated facades. Procedia Environmental Sciences 38: 397-404.

[25] Turkish State Meteorological Service 2020. [Online]. Available at: https://mgm.gov.tr/eng/forecast-cities.aspx. [Accessed: 03-Nov-2020]

[26] Yaşar Y, Maçka Kalfa S (2012) The effects of window alternatives on energy efficiency and building economy in high-rise residential buildings in moderate to humid climates. Energy Conversion and Management 64(4): 170-181.

[27] [Online]. Available: https://www.coruhedas.com.tr/BilgiDanisma/Gunc elTarifeler. [Accessed: 05-Nov-2020]

[28] [Online]. Available: https://www.aksadogalgaz.com.tr/Musteri-
Hizmetleri/Fiyat-Tarifeleri/Satis-

Tarifesi/TrabzonRize. [Accessed: 05-Nov-2020]

\section{Nomenclature}

$I \quad$ Initial capital investment

$M-R-O \quad$ Maintain-Repair-Operation cost

$R \quad$ Replacement cost

$R V \quad$ Residual value 